\title{
EKSTRAKSI, UJI AKTIVITAS ANTIOKSIDAN DAN IDENTIFIKASI GOLONGAN SENYAWA AKTIF ALGA MERAH Eucheuma spinosum DARI PERAIRAN BANYUWANGI
}

\author{
Ulfatul Mardiyah, A. Ghanaim Fasya, Begum Fauziyah, Suci Amalia
}

Jurusan Kimia, FakultasSainsdanTeknologi, UIN Maulana Malik Ibrahim Malang

\begin{abstract}
Antioxidant activity assay and active compound identification red algae Euchemaspinosum extract was conducted. Active compound extraction was conducted using maceration method with methanol. Metabolite separation was conducted using hydrolyzed process with $\mathrm{HCl} 2 \mathrm{~N}$, continued with partition extraction using various solvent 1-buthanol, ethyl acetate, chloroform, petroleum ether and n-hexane. Antioxidant activity assay using DPPH method with determining $\mathrm{EC}_{50}$ value. The highest antioxidant activity at petroleum ether, followed by chloroform fraction, methanol, ethyl acetate, 1-buthanol and n-hexane with $\mathrm{EC}_{50}$ value respectively 12.65 ppm, 19.23 ppm, 22.13 ppm, 41.94 ppm, $73.02 \mathrm{ppm}$ and $80.32 \mathrm{ppm}$. Containing compounds that exist in petroleum ether fraction were flavonoid, triterpenoid, alkaloid and ascorbic acid.
\end{abstract}

Key Word :antioxidant activity, DPPH method,Eucheuma spinosum

\section{ABSTRAK}

Pengujian aktivitas antioksidan dan identifikasi senyawa aktif ekstrak alga merah Eucheuma spinosum telah dilakukan. Ekstraksi senyawa aktif dilakukan dengan metode maserasi menggunakan metanol. Pemisahan metabolitnya dilakukan dengan proses hidrolisis dengan $\mathrm{HCl} 2 \mathrm{~N}$, dilanjutkan dengan ekstraksi partisi menggunakan pelarut 1-butanol, etilasetat, kloroform, petroleum eterdan n-heksana. Pengujian aktivitas antioksidan menggunakan metode $\mathrm{DPPH}$ dengan menentukan nilai $\mathrm{EC}_{50}$. Aktivitas antioksidan tertinggi pada fraksi petroleum eter, diikut ioleh fraksi kloroform, metanol, etilasetat, 1-butanol dan n-heksanadengan nilai $\mathrm{EC}_{50}$ masing-masing 12,65 ppm, 19,23 ppm, 22,13 ppm, 41,94 ppm, 73,02 ppm dan 80,32 ppm. Kandungan golongan senyawa yang terdapat dalam ekstrak petroleum eter adalah flavonoid, triterpenoid, alkaloid dan asam askorbat.

Kata Kunci : aktivitas antioksidan, metode DPPH, Eucheuma spinosum

\section{PENDAHULUAN}

Indonesia merupakan negara bahari dengan keanekaragaman hayati laut terbesar di duniayang memiliki total luas perairan Nusantara seluas 2,8 juta $\mathrm{Km}^{2}$, dan laut teritorial seluas 0,3 juta $\mathrm{mm}^{2}$ (Kusumastanto, 2011). Salah satu sumber daya alam yang terdapat di laut dan dapat dimanfaatkan adalah alga merah.

Alga baik yang liar maupun yang telah dibudidayakan secara tradisional digunakan sebagai obat diet (Wibowo, 2001), bahan makanan dan obat-obatan, karena kaya akan protein, lipid, vitamin dan mineral yang sangat penting bagi manusia. Temuan terakhir membuktikan bahwa rumput laut berpotensi sebagai antivirus (Manilal, dkk., 2009), antibakteri (Izzati, 2007), antijamur (Khazanda, dkk., 2007), antitumor (Zandi, dkk., 2010) dan antioksidan (Lestario, dkk., 2008).

Yan dkk.(1998) menyebutkan bahwa antioksidan memiliki peranan penting dalam mencegah oksidasi radikal bebas yang dapat menyebabkan berbagai penyakit seperti karsinogenik dan penuaan. Radikal bebas adalah molekul yang memiliki satu atau lebih elektron yang tidak berpasangan di orbital terluar. Banyak dari radikal bebas adalah dalam bentuk oksigen dan nitrogen reaktif (Wong, 2000). Saat ini antioksidan yang umum digunakan merupakan antioksidan sintetik diantaranya 
butil hidroksianisol (BHA), butilated hidroksitoluena (BHT), propylgallate $(\mathrm{PG})$ dan tetrabutil hidroksitoluena (TBHQ) (Sherwin, 1990). Akan tetapi, senyawa tersebut dicurigai dapat menyebabkan kerusakan hati dan karsinogenik pada hewan uji (Wichi, 1988; Grice, 1986). Oleh karena itu, pengembangan serta pemanfaatan antioksidan yang lebih efektif dan berasal dari alam sangat penting untuk dilakukan (Oktaydkk., 2003).

Berdasarkan Faten dkk. (2009), ekstrak alga merah gracilariaverrucosa fraksi metanol yang dipartisi menggunakan etil asetat, 1-butanol dan petroleum eter, menunjukkan bahwa fraksi metanol, etil asetat dan petroleum eter merupakan fraksi yang cukup aktif dalam menghambat radikal bebas menggunakan DPPH dengan nilai $\mathrm{IC}_{50}$ masing-masing 85, 130 dan 135 ppm. Selain itu, Nihlati dkk. (2008) melaporkan bahwa senyawa kuersetin dari golongan flavonoid larut baik dalam pelarut eter, dan hasil pengujian aktivitas antioksidannya didapatkan nilai $\mathrm{IC}_{50}$ sebesar 4,60 ppm yang mencerminkan bahwasanya fraksi petroleum eter yang mengandung kuersetin memiliki aktivitas antioksidan yang sangat kuat.

Beberapa penelitian menunjukkan bahwa kandungan senyawa antioksidan pada rumput laut terutama berupa senyawa antioksidatif polifenol yang dapat menghambat oksidasi radikal bebas. Halimada sp. yang tergolong alga coklat menunjukkan tentang adanya bermacammacam senyawa antioksidan, seperti catechin, epicatechin, epigallocatechin, catechin gallate, epigallocatechin gallate, rutin, quercitrin (Sriwardhana2003), alga merah jenis Laurencia obtuse mengandung senyawa triterpenoid (Gamal, 2011).Hasil uji fitokimia metabolit sekunder dalam ekstrak alga merah Gelidium acerosa menggunakan pelarut etanol dan aseton menunjukkan adanya beberapa golongan senyawa seperti alkaloid, saponin, flavonoid, steroid dan tanin (Elsie dkk., 2011).
Sebagai salah satu upaya untuk mengungkapkan sifat biologis dan medis dari flora laut serta untuk mengoptimalkan pemanfaatan bahan alam laut Indonesia, khususnya di daerah Banyuwangi maka sangat perlu dilakukan penelitian tentang aktivitas antioksidan alga merah Eucheuma spinosum.

\section{METODE PENELITIAN}

\section{Pelaksanaan Penelitian}

Penelitian ini dilaksanakan di Laboratorium Kimia Organik dan Laboratorium Bioteknologi Jurusan Kimia Universitas Islam Negeri (UIN) Maulana Malik Ibrahim Malang pada bulan MaretAgustus 2012.

\section{Alat dan Bahan}

Alat-alat yang digunakan dalam penelitian ini adalah seperangkat alat gelas, neraca analitik, mortar, pisau, kertas saring, corong buchner vacum, inkubator, rotary evaporator vacum, shaker, vortex, corong pisah, desikator, oven dan spektrofotometer UV-Vis Varian Carry, spektronik 20+.

Bahan sampel yang digunakan dalam penelitian ini adalah alga merah jenis (Eucheuma spinosum) berasal dari laut Wongsorejo Banyuwangi.

Bahan-bahan kimia yang digunakan adalah metanol, kloroform, $n$-heksana, etil asetat, 1-butanol $\mathrm{DPPH}, \mathrm{KMnO}_{4} 0,1 \%$, petroleum eter, BHT, standar vitamin $\mathrm{C}$, $\mathrm{HCl} 37 \%, \mathrm{HCl} 2 \mathrm{~N}$, etanol $95 \%, \mathrm{H}_{2} \mathrm{SO}_{4}$ pekat, natrium bikarbonat, asam asetat anhidrida, amonia, aseton, pereaksi Mayer dan Dragendorff, dan serbuk logam Mg.

\section{Cara Kerja}

\section{PreparasiSampel}

Alga merah sebanyak $4 \mathrm{~kg}$ dicuci dengan air, kemudian diiris kecil-kecil lalu dioven pada suhu $38^{\circ} \mathrm{C}$ selama 24 jam dan dihaluskan menggunakan blender hingga halus. Serbuk alga merah diayak menggunakan ayakan yang berukuran 60250 mesh.

\section{Ekstraksi Alga Merah}

Sebanyak100 g dan diekstraksi secara maserasi menggunakan $300 \mathrm{~mL}$ 
pelarut metanol selama 24 jam dan dilakukan pengocokan menggunakan shaker dengan kecepatan $150 \mathrm{rpm}$ (rotation per minutes), proses ekstraksi dilakukan sebanyak 5 kali pengulangan. Sebanyak 5 gram ekstrak pekat metanol kemudian dihidrolisis dengan $10 \mathrm{~mL} \mathrm{HCl}$ dan dinetralkan dengan $\mathrm{NaHCO}_{3}$. hidrolisat yang diperoleh dipartisi (ekstraksi cair-cair) dengan pelarut 1-butanol, etilasetat, kloroform, petroleum eterdan $n$-heksana.

UjiAktivitas Antioksidan dengan DPPH

Penentuan Panjang Gelombang
Maksimum

Larutan DPPH 0,2 mM sebanyak 5 $\mathrm{mL}$ dimasukkan ke dalam tabung reaksi lalu didiamkam \pm 10 menit. Kemudian dimasukkan ke dalam kuvet. Dicari $\lambda_{\text {maks }}$ larutan dan dicatat hasil pengukuran $\lambda_{\text {maks }}$ untuk digunakan pada tahap selanjutnya (Rahayudkk., 2010).

\section{Penentuan Waktu Kestabilan}

Larutan ekstrak 200 ppmdibuat sebanyak $25 \mathrm{~mL}$, kemudian diambil sebanyak 4,5 mL. Ditambahkan 0,2 mM larutan DPPH sebanyak 1,5 mL, lalu diinkubasi, dan dicari waktu kestabilan pada rentangan waktu 5-120 menit dengan interval 5 menit. Sampel diukur pada $\lambda_{\text {maks }}$ dan waktu kestabilan yang telah didapatkan.

Pengukuran Potensi Antioksidan Sampel

Absorbansi kontrol: Larutan DPPH dengan konsentrasi $0,2 \mathrm{mM}$ sebanyak $5 \mathrm{~mL}$ dimasukkan ke dalam tabung reaksi, lalu diinkubasi pada suhu $37^{\circ} \mathrm{C}$ selama waktu kestabilan yang telah didapatkan pada tahap sebelumnya, setelah itu larutan dimasukkan ke dalam kuvet hingga penuh dan diukur absorbansinya pada $\lambda_{\text {maks }}$ yang didapatkan.

Sampel dari masing-masing fraksi dilarutkan dalam pelarutnya dengan konsentrasi 1, 5, 25, 50, 100, 150 dan 200 ppm. Dimasukkankedalamtabungreaksi 4.5 mL ekstrak dan ditambahkan DPPH sebanyak $1.5 \mathrm{~mL}$ (perbandingan larutan DPPH : ekstrak yang dilarutkan dengan konsentrasi tertentu 1:3). Perlakuan tersebut diulangi sebanyak tiga kali. Setelah itu diinkubasi dengan suhu $37{ }^{\circ} \mathrm{C}$ pada waktu kestabilan yang didapatkan pada tahap 41 sebelumnya, lalu diukur absorbansinya pada $\lambda_{\text {maks. }}$ Data absorbansinya yang diperoleh dari tiap konsentrasi masingmasing ekstrak dihitung nilai persen $(\%)$ aktivitas antioksidannya. (Arindah, 2010).

\section{Identifikasi Senyawa Aktif Flavonoid}

Ekstrak kasar $5 \mathrm{mg}$ ditambahkan dengan air panas 1-2 mL air panas dan sedikit serbuk Mg. Kemudian ditambahkan 4-5 tetes $\mathrm{HCl} 37 \%$ dan etanol $95 \%$ dengan volume yang sama lalu dikocok. Jika menunjukkan warna merah, kuning atau jingga maka ekstrak kasar positif mengandung flavonoid (Febriany, 2004).

\section{Alkaloid}

Ekstrak kasar dimasukkan dalam tabung reaksi, ditambah $0,5 \mathrm{~mL} \mathrm{HCl} 2 \%$ dan larutan dibagi dalam dua tabung. Tabung I ditambahkan 2-3 tetes reagen Dragendorff, tabung II ditambahkan 2-3 tetes reagen Mayer. Jika tabung I terbentuk endapan jingga dan pada tabung II terbentuk endapan kekuning-kuningan, menunjukkan adanya alkaloid.

\section{Steroid/Terpenoid}

Ekstrak kasar diambil $5 \mathrm{mg}$ dilarutkan dalam 2-3 mL kloroform, lalu ditambahkan 10 tetes asam asetat anhidrida dan 2-3 tetes $\mathrm{H}_{2} \mathrm{SO}_{4}$ pekat melalui dinding tabung, jika terbentuk warna biru sampai hijau menunjukkan adanya steroid, sedangkan jika hasil yang diperoleh berupa cincin kecoklatan atau violet pada perbatasan dua pelrut menunjukkan adanya triterpenoid (Auterhoff dkk., 1987).

\section{Asam Askorbat}

Ekstrak kasar diambil $5 \mathrm{mg}$ dilarutkan dalam aquadest $5 \mathrm{~mL}$, kemudian ditambahkan 10 mL larutan $\mathrm{KMnO}_{4}$ 0,1\%. Jika terbentuk warna cokelat maka menunjukkan adanya asam askorbat (Auterhoff dkk., 1987).

\section{HASIL DAN PEMBAHASAN Preparasi Sampel}

Alga merah (Eucheuma spinosum) dicuci hingga bersih untuk menghilangkan pasir maupun lumpur yang menempel pada 
tallusnya, kemudian dioven pada suhu $38^{\circ} \mathrm{C}$ selama 24 jam, tujuan pengeringan ini untuk meminimalisir kadar air yang terkandung dalam alga merah dan untuk menghambat aktivitas mikroorganisme (jamur maupun bakteri) agar dapat disimpan dalam jangka waktu yang cukup lama (Winarno, 1995).

Alga merah yang sudah kering dipotong kecil-kecil untuk memudahkan proses pemblenderan, setelah itu sampel diblender hingga halus, dan disaring menggunakan penyaring (ayakan) dengan ukuran 60-250 mesh. Tujuan penghalusan sampel yaitu untuk memperbesar ukuran permukaan sampel sehingga proses ekstraksi berjalan optimal karena semakin luas permukaan sampel maka interaksi antara pelarut dan sampel semakin besar. Hasil yang diperoleh dari proses ini menunjukkan bahwa dari $4 \mathrm{~kg}$ sampel basah didapatkan serbuk alga merahsebanyak 350 gram. Selain itu, serbuk alga merahberwarna coklat dan berbau menyengat.

\section{Ekstraksi Alga Merah}

Ekstrak pekatfraksimetanol yang diperoleh berupa padatan berwarna hijau pekat. Sedangkan rendemen ekstrak pekat metanol ditunjukkan pada Tabel 1.

Tabel 1. Hasil ekstraksi dan rendemen ekstrak metanol

\begin{tabular}{l|c}
\hline \multicolumn{1}{c|}{ Ekstrak } & Rendemen \% (b/b) \\
\hline EkstrakMetanol 1 & 19,17 \\
EkstrakMetanol 2 & 14,35 \\
EkstrakMetanol 3 & 15,29 \\
Rata-rata & 16,25 \\
\hline
\end{tabular}

Hidrolisis ekstrak pekat metanol dengan $\mathrm{HCl} 2 \mathrm{~N}$ berfungsi untuk memecah ikatan glikosida antara komponen gula (glikon) dan metabolit sekunder (aglikon), karenaumumnya di alam metabolit sekunder ditemukan dalam bentuk glikosida. Dugaan reaksi yang terjadi saat proses hidrolisis ditunjukkan Gambar 1.

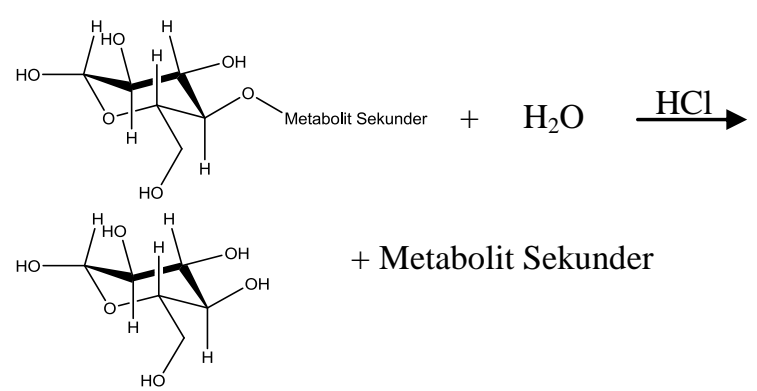

Gambar 1 Hidrolisis glikosida

Selanjutnya hidrolisat dipartisi menggunakan variasi pelarut yang memiliki kepolaran yang berbeda, yaitu 1-butanol, etil asetat, kloroform, petroleum eter dan $n$ heksana, pemilihan pelarut ini dimaksudkan agar senyawa-senyawa yang memiliki kepolaran berbeda dapat terekstrak ke dalam pelarut yang sesuai (Voight, 1994), sehingga dalam proses ini terdapat dua lapisan yang tidak saling bercampur, dan diduga palarut yang bersifat polar (fase air) akan mengekstrak komponen gula (glikon), sedangkan pelarut semi polar maupun non polar (fase organik) akan mengekstrak metabolit sekunder (aglikon) yang sudah terpisah dengan komponen gula yang diduga aktif sebagai antioksidan.Rendemen masing-masingfraksiyang diperoleh dari 5 gram berat ekstrak pekat metanol disajikan pada Tabel 2.

Tabel 2 Hasil ekstraksi dan rendemen untuk masing-masing fraksi hasil partisi

\begin{tabular}{lcc}
\hline Pelarut & $\begin{array}{c}\text { Warna } \\
\text { ekstrak } \\
\text { pekat }\end{array}$ & $\begin{array}{c}\text { Rendemen } \\
(\boldsymbol{\%}) \mathbf{( b / b )}\end{array}$ \\
\hline 1-butanol & Hitam & 6,04 \\
Etil asetat & Hijau & 16,20 \\
Kloroform & $\begin{array}{c}\text { Coklat } \\
\text { kehitaman } \\
\text { Hijau }\end{array}$ & 6,24 \\
Petroleum & $\begin{array}{c}\text { eter } \\
n \text {-heksana }\end{array}$ & $\begin{array}{c}\text { kehitaman } \\
\text { coklat } \\
\text { kehitaman }\end{array}$ \\
\hline
\end{tabular}


Uji Aktivitas Antioksidan dengan DPPH Penentuan Panjang Gelombang Maksimum

Pengujian aktivitas antioksidan menggunakan metode DPPH diawali dengan penentuan panjang gelombang maksimum. Tujuan dari penentuan panjang gelombang maksimum untuk mengetahui panjang gelombang yang memiliki serapan tertinggi. Hasil yang diperoleh menunjukkan bahwa panjang gelombang maksimum larutan DPPH sebesar 515,1 nm dengan nilai serapan 0,831 .

\section{Penentuan Waktu Kestabilan}

Pengukuran waktu kestabilan dilakukan untuk mengetahui waktu dimana sampel dan DPPH sudah bereaksi secara stabil yakni sempurnanya reaksi antara sampel dan DPPH yang ditunjukkan dengan tidak adanya lagi penurunan absorbansi (Ludkk.,2001). Setiap senyawa memiliki waktu kestabilan yang berbeda untuk dapat bereaksi secara sempurna (BrandWilliamdkk., 2001), sehingga penentuan waktu kestabilan masing-masing sampel sangat penting untuk dilakukan. Pengukuran ini dilakukan dengan proses inkubasi pada rentang waktu 5-120 menit, sedangkan rentang waktu yang digunakan untuk fraksi $n$-heksana dan 1-butanol adalah 5-150 menit. Hasil penentuan waktu kestabilan dari masing-masing fraksi disajikan pada Tabel 3.

Tabel 3 Waktu kestabilan masing-masing ekstrak

\begin{tabular}{l|r}
\hline \multicolumn{1}{c|}{ Sampel } & $\begin{array}{r}\text { Waktu kestabilan } \\
\text { (Menit) }\end{array}$ \\
\hline Vitamin C & $25-50$ \\
BHT & $80-120$ \\
Metanol & $25-75$ \\
1-butanol & $125-150$ \\
Ekstrak Etil Asetat & $20-80$ \\
Kloroform & $90-120$ \\
Petroleum Eter & $70-90$ \\
Ekstrak $n$-heksana & $120-150$ \\
\hline
\end{tabular}

Pengukuran Potensi Antioksidan Pada Sampel

Pengukuran aktivitas antioksidan tiap-tiap konsentrasi pada sampel harus menggunakan larutan kontrol yang berupa larutan DPPH 0,2 mM. Larutan DPPH kontrol digunakan untuk memberikan kestabilan pada saat pengukuran aktivitas antioksidan pada sampel (Arindah, 2010). Menurut Molyneux (2003) nilai absorbansi kontrol dapat berkurang dari hari ke hari dikarenakan kehilangan aktivitasnya saat dalam stok larutan DPPH, tetapi nilai absorbansi kontrol tetap dapat memberikan baseline untuk pengukuran saat itu

Absorbansi kontrol maupun absorbansi sampel yang diperoleh selanjutnya digunakan untuk menentukan persen (\%) aktivitas antioksidan. Persen (\%) aktivitas antioksidan merupakan salah satu parameter yang menunjukkan kemampuan suatu antioksidan dalam menghambat radikal bebas. Semakin tinggi persen (\%) aktivitas antioksidan menunjukkan banyaknya atom hidrogen yang diberikan senyawa aktif kepada radikal DPPH sehingga tereduksi menjadi DPPH-H (1,1-difenil-2-pikrilhidrazin) (Rahayu, et al., 2010). Banyaknya atom hidrogen yang didonorkan oleh molekul antioksidan dapat diketahui secara kualitatif dengan terjadinya perubahan warna radikal DPPH dari ungu menjadi kuning. Hasil pengukuran masing-masing ekstrak ketika ditambahkan larutan DPPH tidak mengalami perubahan warna dari ungu menjadi kuning, melainkan hanya terjadi pemudaran warna dari ungu menjadi pink keunguan. Berikut nilai persen aktivitas masing-masing fraksi. 
Tabel 4 Persen aktivitas antioksi dan masing-masing fraksi

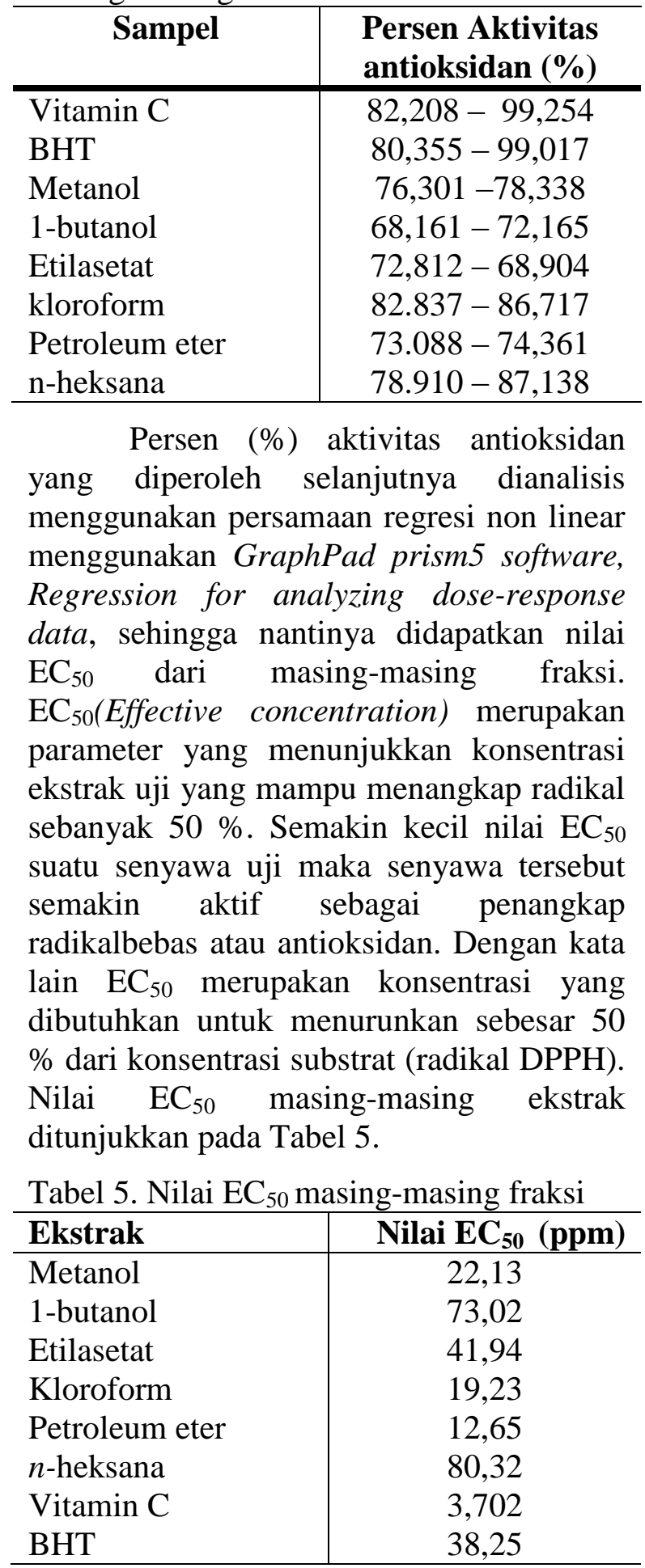

Sampel yang memiliki aktivitas antioksidan tertinggi ada pada fraksi petroleum eter, hal itu diduga karena pelarut petroleum eter dapat mengekstrak senyawa-senyawa fenol yang memiliki tingkat kepolaran yang rendah dan berfungsi sebagai antioksidan. Nihlatidkk.
(2008) melaporkan bahwa senyawa kuersetin dari golongan flavonoid larut baik dalam pelarut eter, dan hasil pengujian aktivitas antioksidannya didapatkan nilai $\mathrm{IC}_{50}$ sebesar 4,60 ppm yang mencerminkan bahwasanya fraksi petroleum eter yang mengandung kuersetin memiliki aktivitas antioksidan yang sangat kuat.

\section{Identifikasi Senyawa Aktif}

Identifikasi senyawa aktif yang terdapat dari ekstrak metanol, 1-butanol, etil asetat, kloroform, petroleum eter dan $n$ heksana dilakukan dengan penambahan reagen-reagen dan diamati secara kualitatif. Hasil identifikasi golongan senyawa aktif yang terdapat dalam masing-masing ekstrak ditunjukkan pada Tabel 6 .

Tabel 6. Hasil identifikasi senyawa aktif estrak alga merah E. spinosum

\begin{tabular}{|c|c|c|c|c|c|c|}
\hline \multirow{2}{*}{$\begin{array}{l}\text { Golongan } \\
\text { Senyawa }\end{array}$} & \multicolumn{6}{|c|}{ Pelarut } \\
\hline & $\begin{array}{c}\text { Metan } \\
\text { ol }\end{array}$ & $\begin{array}{c}1- \\
\text { butan } \\
\text { ol }\end{array}$ & $\begin{array}{c}\text { Etil } \\
\text { asetat }\end{array}$ & $\begin{array}{c}\text { Klorof } \\
\text { orm }\end{array}$ & $\begin{array}{l}\text { Petrole } \\
\text { um eter }\end{array}$ & $\begin{array}{c}\mathrm{n}- \\
\text { Heksan } \\
\text { a }\end{array}$ \\
\hline Flavonoid & +++ & - & - & - & + & - \\
\hline $\begin{array}{l}\text { Triterpeno } \\
\text { id }\end{array}$ & ++ & + & +++ & +++ & +++ & +++ \\
\hline $\begin{array}{l}\text { Steroid } \\
\text { Alkaloid }\end{array}$ & - & - & - & ++ & - & + \\
\hline - Mayer & - & - & - & + & + & - \\
\hline $\begin{array}{l}\text { - Dragen } \\
\text { drof }\end{array}$ & - & ++ & ++ & - & + & + \\
\hline $\begin{array}{l}\text { Asam } \\
\text { askorbat }\end{array}$ & + & + & + & + & + & + \\
\hline
\end{tabular}

Berbagai golongan senyawa yang terdapat dalam alga merah E. spinosum sangat berperan penting dalam pengujian aktivitas antioksidan. Hasil pengujian aktivitas antioksidan menunjukkan bahwa sampel alga merah $E$. spinosum sangat aktif sebagai antioksidan dengan melihat dari nilai $\mathrm{EC}_{50}$ masing-masing fraksi yang berkisar antara 12-80 ppm yang menunjukkan alga merah E. spinosum memiliki aktivitas antioksidan yang sangat kuat. 


\section{KESIMPULAN DAN SARAN Kesimpulan}

Ekstrak alga merah E. spinosum yang memiliki aktivitas antioksidan tertinggi pada penelitian ini adalah ekstrak petroleum eter dengan nilai $\mathrm{EC}_{50}$ sebesar 12,65 ppm, nilai $\mathrm{EC}_{50}$ yang diperoleh mencerminkan ekstrak petroleum eter memiliki aktivitas antioksidan yang sangat kuat. Aktivitas antioksidan yang dimiliki oleh ekstrak petroleum eter didukung oleh kandungan berbagai senyawa aktif di dalamnya seperti senyawa flavonoid, triterpenoid, alkaloid dan asam askorbat.

\section{Saran}

Diperlukan pengujian aktivitas antioksidan dengan konsentrasi yang lebih tinggi agar dapat diketahui pada konsentrasi berapa sampel bersifat prooksidan.

Diperlukan penelitian lebih lanjut dengan memisahkan golongan senyawa aktif ekstrak kasar alga merah E.spinosum dan identifikasi senyawa dengan FTIR, GC/LC-MS agar dapat diketahui senyawa yang berpotensi sebagai antioksidan.

\section{DAFTAR PUSTAKA}

Arindah, D. 2010. Fraksinasi dan Identifikasi Golongan Senyawa Antioksidan pada Daging Buah Pepino (Solonum Muricatum aiton) yang Berpotensi Sebagai Antioksidan. Skripsi Tidak Diterbitkan. Malang: Jurusan Kimia Fakultas Sains dan Teknologi Universitas Islam Negeri (UIN) Maulana Malik Ibrahim Malang.

Auterhoff, H., dan Kovar, K.A. 1987. Identifikasi Obat, Bandung: ITB.

Brand, W.W. 1995.Use of Free Radical Method to Evaluate Antioxidant activity. London: Elsivier Applied Science. LebensmettelWissenschaftand Technology.
Elsie, B. H., Dhanarajan, M. S., \&Sudha, P. N. 2011.Invitro Screening Of Secondary Metabolites And Antimicrobial Activities Of Ethanol And Acetone Extracts From Red Seaweed GelidiumAcerosa. JournalOfChemistry Research. India: Department Of BioChemistry, Jaya College of Arts and Science, Thirunindravur, TamilNadu.2(2), 1-3.

Faten, M., Abou, E., and Emad, A.S. 2009. Antioxidant Activity of Extract and Semi-Purified Fractions of Marine Red Macroalga, Gracilaria Verrucosa.Australian. Journal of Basic and Applied Sciences. Kairo: Biochemistry Department, Faculty of Agriculture, Cairo University. 3(4), 3179-3185.

Febriany, $\mathrm{S}$. 2004. PengaruhBeberapaEkstrak Tunggal Bangle danGabungannya yang BerpotensiMeningkatkanAktivitasEn zim Lipase SecaraIn Vitro. Skripsitidakditerbitkan. Bogor: Fakultas MIPA IPB.

Gamal, E., Ali, A. 2011.Biological Importance of Marine Algae.Biotechnology. KSA: Department of Pharmacognosy, College of Pharmacy, King Saud University.

Grice, H.C., 1986. Safety Evaluation of ButylatedHydroxy Toluene (BHT) in The Liver, Lung and Gastrointestinal Tract. Journal of Food Chemistry and Toxicology. 24: 1127-1130.

Izzati, M. 2007. Skreening Potensi Antibakteri pada Beberapa Spesies Rumput Laut terhadap Bakteri Patogen pada Udang Windu. Jurnal BIOMA. Semarang: Universitas. Vol. 9, No. 2. $62-67$.

Khazanda, K.A., Wazir, S.T.G., Samina, K., Shahzadi, S. 2007. Antifungal Activity, Elemental Analysis And Determination Of Total Protein Of Seaweed, Solieria Robusta 
(Greville) Kylin From The Coast Of

Karachi. National Center of Excellence for Aanalytical Chemistry. Pakistan: University of Sindh, Jamshoro-76080.

Kusumastanto, T. 2011. Pengembangan Sumberdaya Kelautan Dalam Memperkokoh Perokonomian Nasional Abad 21.Tugas Akhir Tidak Diterbitkan. Bogor: Insitut Pertanian Bogor.

Lestario, N.L., Sugiarto, S., Timotius, K.H. 2008. Aktivits antioksidan dan Kadar Fenolik Total dari Ganggang Merah (Gracilaria Verucosa). Jurnal Teknologi dan Industri Pangan. Salatiga: Universitas Kristen Satya Wacana. Vol XIX No 2.

Lu Y., Foo F.Y. 2000. Antioxidant and Radical Scavenging Activities of Polyphenols from Apple. Journal of Food Chemistry, 68: 81-85.

Manilal. A., Sujith, S., Selvin, J., Kiran, G.S., Shakir, C. 2009. In vivo Antiviral Activity of Polysaccharide from the Indian Green Alga, Acrosiphonia orientalis (J. Agardh): Potential Implication in Shrimp Disease Management, Journal of Fish and Marine Sciences. Department of Microbiology. India: Bharathidasan University. 1 (4): 278-282.

Molyneux, P., 2003, The Use of The Stable Free Radical Diphenylpicrylhydrazyl (DPPH), for Estimating Antioxidant Activity. Journal of Science and Technology. Institute of Food Research Colney, Norwich, United Kingdom. Vol 26(2) : 211-219.

Nihlati, I., Abdul, R., Triana, H. 2008. Daya Antioksidan Ekstrak Etanol Rimpang Temu Kunci [Boesenbergia pandurata (roxb.) Schlecth] dengan Metode Penangkapan Radikal DPPH $(1,1$ difenil-2-pikrilhidrazil). Skripsi diterbitkan. Yogyakarta: Universitas Gadjah Mada.

Oktay, M., Gulcin, I., and Kufrevioglu, O. 2003. Determination of In Vitro Antioxidant Activity of Fennel (Foeniculum Vulgare) Seed Extract. Journal Of Food Science \& Technology. London: Published/Hosted by Elsevier Science. Lebensmittel-Wissenchaft and Technology, Vol. 36: 263-271.

Rahayu, D.S., Dewi, K., Enny, F. 2010. PenentuanAktivitas Antioksidan dari Ekstrak Etanol Daun Ketapang (Terminalia catappa L) dengan Metode 1,1 difenil 2 Pikrilhidrazil $(D P P H) . \quad$ Skripsi Diterbitkan. Semarang: Jurusan Kimia FMIPA Universitas Diponegoro.

Sherwin, F.R., 1990. Antioxidant. In: Food Additive (ed. Branen R). New York: Marcel Dekker.

Wichi, H.P., 1988. Enhanced Tumor Development By Butylated Hydroxyanisole (BHA) From The Prospective of Effect on Forestomach and Oesophageal Squamous Epithelium. Journal Of Food Chemistry and Toxicology. Vol. 26: 717-723.

Wibowo, S.T. 2001. Potensi Jenis-Jenis Rumput Laut dari Pantai Sayang Heulang-Pameungpeuk Garut Sebagai Antibakteri Escherichia coli. Jurnal Biologi. Bogor: Jurusan biologi, Institut Pertanian Bogor

Winarno F.G. 1995. Kimia Pangan dan Gizi. Jakarta: PT, Gramedia Pustaka Utama.

Yan, X., Nagata, T., and Xiao, F. 1998. Antioxidative Activities in Some Common Seaweeds. Journal of Plant Foods for Human Nutrition Institute of Oceanology. Japan: Academic Publisher. 52: 253-262. 